\title{
Diabetes and glucose tolerance in New South Wales coastal Aborigines: possible effects of non-Aboriginal genetic admixture
}

\author{
D.R.R.Williams ${ }^{1}$, P.S. Moffitt ${ }^{2}$, J.S. Fisher ${ }^{3}$ and H.V. Bashir ${ }^{4}$ \\ ${ }^{1}$ University Department of Community Medicine, Addenbrooke's Hospital, Cambridge, UK; \\ ${ }^{2}$ Diabetic Education and Stabilisation Centre, Royal Newcastle Hospital, Newcastle, \\ ${ }^{3}$ Biripi Medical Centre, Taree, ${ }^{4}$ Australian Red Cross Society, Sydney, New South Wales, Australia
}

\begin{abstract}
Summary. A survey of adults living in two predominantly Aboriginal communities in eastern New South Wales revealed a crude prevalence of clinically diagnosed diabetes of $6.7 \%$ in Aboriginals. $1.4 \%$ of Aboriginal subjects investigated with $75 \mathrm{~g}$ oral glucose tolerance tests were found to have previously undiagnosed diabetes, and $2.8 \%$ had impaired glucose tolerance. $53 \%$ of women and $27 \%$ of men were obese as judged by body mass index. The age-sex standardised prevalence of diabetes in Aboriginals (previously diagnosed and newly detected) was $7.8 \%$, which is substantially lower than the $15.6 \%$ prevalence found in the Aboriginal population of Bourke (central New South Wales). HLA antigen studies on these same individuals suggest approximately $60 \%$ genetic admix-
\end{abstract}

ture from non-Aboriginal sources. Insulin response to oral glucose and mean body mass index were both related to nonAboriginal genetic admixture with higher values in Aboriginal subjects than in their non-Aboriginal neighbours, and highest values were found in those with no detectable non-Aboriginal HLA haplotypes. The extent of genetic admixture in these communities may partly explain the lower prevalence of diabetes when compared with that found in the Aboriginal population of Bourke.

Key words: Diabetes, Australian Aborigines, HLA antigens, insulin response, obesity, genetic influence.
The indigenous people of Australia are known [1-5] to have a higher prevalence of diabetes than non-Aboriginal Australians [6, 7]. Crude prevalence estimates for diabetes in adult Australian Aborigines range from 11\% [2] to $19 \%$ [1]. Though less than the striking preyalences found elsewhere in the Pacific [8], these rates suggest a major public health problem and are of considerable interest for research into the genetic and environmental causes of Type 2 (non-insulin-dependent) diabetes.

Existing studies of this problem [1-5] differ in many important respects, particularly in the geographic origins of the populations studied, the ways in which individuals were selected for study and the methods used and criteria employed for the detection and diagnosis of diabetes. Almost 15 years separate the data collection of the first study [1] from that of the most recent [5]. Important changes in environmental exposures may have occurred during this time. Despite these differences, all studies suggest that it is Type 2 diabetes which is the common form in these groups. The 'thifty genotype' hypothesis [9] may be of relevance since it is entirely plau- sible that, in the harsh Australian environment of the past, there had been selection for certain metabolic characteristics; these have now become detrimental following recent changes in Aboriginal lifestyle. There is increasing evidence from studies of Pacific populations $[10,11]$. Mexican Americans [12] and North American Indians [13] that genetic admixture in populations known to have a high prevalence of Type 2 diabetes leads to a reduction in prevalence - an apparent 'protective effect' by 'foreign' genetic material.

This study of diabetes in a group of coastal Aborigines in New South Wales documents diabetes prevalence and describes glucose tolerance (including insulin response to oral glucose) in relation to genetic admixture from non-Aboriginal sources as assessed by HLA antigen status. The study was carried out as a first stage in a programme directed towards the detection of diabetes and diabetic complications, improved diabetic control and the prevention of diabetes and obesity in this population. 
Table 1. Age and sex composition of the study population

\begin{tabular}{lcccccc}
\hline Age group & \multicolumn{2}{c}{ Men $^{\mathrm{a}}$} & & \multicolumn{2}{l}{ Women } & \multirow{2}{*}{ Total } \\
\cline { 2 - 3 } & Purfleet & Forster & & Purfleet & Forster & \\
\hline $18-24$ & 26 & 13 & 14 & 9 & 62 \\
$25-34$ & 23 & 16 & & 14 & 10 & 63 \\
$35-44$ & 8 & 8 & 8 & 8 & 32 \\
$45-54$ & 10 & 8 & 9 & 5 & 32 \\
$55-64$ & 5 & 2 & 6 & 5 & 18 \\
65 and over & 3 & 2 & 3 & 3 & 12 \\
All ages & 75 & 50 & 54 & 40 & 219 \\
\hline
\end{tabular}

a Numbers of individuals are given

\section{Subjects and methods}

\section{Subjects}

The study population consisted of the adult inhabitants (those aged 18 and over) of Purfleet and of the Aboriginal settlement at Forster, New South Wales. Purfleet is $2 \mathrm{~km}$ south of Taree, a town about $300 \mathrm{~km}$ north of Sydney. Forster is $45 \mathrm{~km}$ from Taree. These settlements were chosen for study because they gave access to a group of coastal New South Wales Aborigines hitherto unstudied in relation to diabetes. In addition, medical care was provided almost solely by the staff based at one medical centre, the Board of Governors of which was supportive of the project. Most, though not all (detailed below), inhabitants regard themselves, and are regarded by others, as Aboriginal according to the current officially accepted definition, viz. a person of Aboriginal descent who identifies as an Aboriginal and is accepted as such by the community in which he or she lives.

In May 1985 a de jure census was carried out of all households in the two communities. The total enumerated population was 382 , of whom $219(57.3 \%)$ were aged 18 and over. The age-sex composition of the study population is shown in Table 1 .

\section{Data collection and blood sampling}

Fieldwork was undertaken in July, September and October 1985. Subjects who gave informed consent were visited at home by one of the authors (DRRW) together with an Aboriginal health worker or community nurse. The subject's weight (in indoor clothing without shoes) was measured with a portable scale (bathroom type with large dial, zeroed before each day's weighings). Height (without shoes) was measured using a portable stadiometer. Demographic information (date of birth, employment status, etc) was collected together with data on the racial origin of each subject's grandparents (classified as fullblood Aboriginal, part Aboriginal, non-Aboriginal or unknown). The Aboriginal field workers provided information on the familial relationships of the subjects.

A modified $(75 \mathrm{~g})$ oral glucose tolerance test (OGTT) was carried out on individuals free of previously diagnosed, adequately documented diabetes (see below for definition). Two blood samples (fasting and $2 \mathrm{~h}$ post-load) were collected from each individual. The first of these was used for fasting serum glucose and insulin. The second for $2 \mathrm{~h}$ serum glucose and insulin estimatations, for $\mathrm{ABO}$ blood grouping and for HLA antigen analyses.

Blood samples for insulin assays were collected in heparinized containers, centrifuged immediately on site and the serum frozen and transported each evening to the Hunter Biochemistry Laboratories at the Royal Newcastle Hospital. Samples for glucose estimation were collected in fluoride oxalate containers and were delivered to the North Coast Pathology Service Laboratory at the Manning River Dis- trict Hospital (Taree) on the day the specimens were taken. Blood for $\mathrm{ABO}$ blood grouping and for HLA antigen determination was transported each day by air to the laboratories of the Australian Red Cross Society Blood Transfusion Service in Sydney. All samples for HLA determination were received by the laboratory within $24 \mathrm{~h}$ of the blood being taken and were processed on the day of receipt.

\section{Laboratory methods}

Insulin was measured by radio immune assay using kits supplied by Pharmacia Diagnostics, Uppsala, Sweden. In the Hunter Biochemistry Service Laboratory, between-assay coefficient of variability for this assay is $7.7 \%$ at $9 \mathrm{mU} / 1$ and $5.8 \%$ at $30 \mathrm{mU} / 1$. Plasma glucose determination was by Hexokinase/Glucose-Phosphatase Dehydrogenase method using reagents supplied by Behring Diagnostics, Melbourne, Australia. In the North Coast Pathology Service Laboratories at Taree this method has a sensitivity of $0.02 \mathrm{mmol} / 1$ and coefficient of variability of $3.3 \%$ at $5 \mathrm{mmol} / 1$ and $1.4 \%$ at $16 \mathrm{mmol} / 1$.

HLA typing was carried out by the standard NIH microlymphocytotoxicity test on Tlymphocyte suspensions for HLA ABC and on B lymphocyte enriched suspensions for HLA DR, DQ and MT. The sera used were standardised against 8 th and 9 th International Histocompatability Workshop typed cells $[14,15]$.

\section{Criteria for diabetes and obesity}

The biochemical criteria for diabetes used in this study are those suggested (for non-pregnant adults) in the latest report on diabetes of the World Health Organization [16]. They are a fasting venous plasma glucose of $7.8 \mathrm{mmol} / 1$ or more or a value $2 \mathrm{~h}$ after $75 \mathrm{~g}$ of oral glucose of $11.1 \mathrm{mmol} / \mathrm{l}$ or more. For impaired glucose tolerance, criteria are a fasting plasma glucose less than $7.8 \mathrm{mmol} / 1$ and a $2 \mathrm{~h}$ value greater than $7.8 \mathrm{mmol} / \mathrm{l}$ but less than $11.1 \mathrm{mmol} / 1$. Subjects diagnosed as having diabetes before the survey was commenced were regarded as diabetic either if results of an OGTT fulfilling the above criteria were available or if a fasting blood glucose greater than $10 \mathrm{mmol} / 1$ was found on testing.

Obesity was defined as a body mass index (weight/height ${ }^{2}$ ) equal to or greater than 27 in men and greater than 25 in women. These definitions accord with those suggested by Bennett [17] and are widely used in the field of diabetes epidemiology.

\section{Statistical analysis}

Comparisons of group means was by Student's t-test or one-way analysis of variance; statistical significance was accepted at $p<0.05$.

\section{Results}

\section{Participation and crude prevalence of diabetes}

Examination of medical records prior to the survey revealed that 16 individuals ( 13 from Purfleet, 3 from Forster) had clinically diagnosed diabetes which fulfilled the above criteria. Four of these were prescribed insulin, 5 oral hypoglycaemic agents and 7 dietary modification alone. The crude prevalence of clinically diagnosed diabetes in this population was therefore $7.3 \%$. Two of the diabetic subjects, however, (both men, one aged 38 and one 70) were known to be non-Aboriginal. The prevalence of diabetes among Aborigines is discussed below. 
Table 2. Participation in the study

\begin{tabular}{|c|c|c|c|c|c|}
\hline & \multicolumn{2}{|l|}{ Men } & \multicolumn{2}{|l|}{ Women } & \multirow[t]{2}{*}{ Total } \\
\hline & Purfleet & Forster & Purfleet & Forster & \\
\hline $\begin{array}{l}\text { Present at } \\
\text { time of survey }\end{array}$ & 63 & 43 & 49 & 38 & 193 \\
\hline \multirow{2}{*}{$\begin{array}{l}\text { Answered } \\
\text { questionnaire, } \\
\text { were weighed, etc }\end{array}$} & 45 & 39 & 41 & 38 & 163 \\
\hline & $\begin{array}{l}(60 \%)^{a} \\
(71 \%)\end{array}$ & $\begin{array}{l}(78 \%) \\
(91 \%)\end{array}$ & $\begin{array}{l}(76 \%) \\
(84 \%)\end{array}$ & $\begin{array}{l}(95 \%) \\
(100 \%)\end{array}$ & $\begin{array}{l}(74 \%) \\
(84 \%)\end{array}$ \\
\hline \multirow{2}{*}{$\begin{array}{l}\text { Answered } \\
\text { questionnaire, } \\
\text { were weighed and } \\
\text { had OGTT }\end{array}$} & 42 & 36 & 35 & 31 & 144 \\
\hline & $\begin{array}{l}(56 \%) \\
(67 \%)\end{array}$ & $\begin{array}{l}(72 \%) \\
(84 \%)\end{array}$ & $\begin{array}{l}(65 \%) \\
(71 \%)\end{array}$ & $\begin{array}{l}(78 \%) \\
(82 \%)\end{array}$ & $\begin{array}{l}(66 \%) \\
(75 \%)\end{array}$ \\
\hline
\end{tabular}

${ }^{a}$ Upper row of percentages is proportion of census population participating. Lower row is proportion of those present who participated

Table 3. Estimates of genetic admixture from Caucasian sources derived from blood group A 2 and 5 HLA antigens

\begin{tabular}{llll}
\hline Antigen & $\begin{array}{l}\text { Gene frequency } \\
\text { in sample }\end{array}$ & $\begin{array}{l}\text { Gene frequency } \\
\text { in Caucasians }\end{array}$ & $\begin{array}{l}\text { \% Caucasian } \\
\text { admixture }\end{array}$ \\
\hline Blood group A2 & 0.032 & 0.041 & $78.0 \%$ \\
HLA A1 & 0.149 & 0.194 & $76.8 \%$ \\
B8 & 0.119 & 0.143 & $83.2 \%$ \\
B12 & 0.081 & 0.142 & $57.0 \%$ \\
A3 & 0.053 & 0.139 & $38.1 \%$ \\
B7 & 0.044 & 0.147 & $29.9 \%$ \\
\hline
\end{tabular}

Of the 219 subjects enumerated in the census, 4 had died and 15 had either moved away before they could be studied or were pregnant at the time and were excluded. In addition, 7 further individuals were absent for the duration of the field work. Thus, the population available for study was 193 individuals. 163 of these agreed to be weighed and measured, and to answer questions on diet, smoking, etc. One hundred and fortyfour of these consented, in addition, to be tested for diabetes. Participation rates (expressed both as proportions of the census population and as proportions of those present and available for study) are shown in Table 2. Participation in Forster was higher than that at Purfleet, and in the latter was higher among women than among men.

During the course of the survey, 3 previously undiagnosed cases of diabetes were found ( 2 men and one woman). Six subjects were found to have impaired glucose tolerance.

\section{Body mass index and obesity}

Obesity, defined by the above criteria, was more common in women than in men $(53 \%$ obese compared with $27 \%$ ). Body mass index in men showed no relationship with age. For women, mean values were lowest in the 18-24 and 25-34 age groups but showed little difference thereafter. There were no significant differences between age specific values of body mass index found in this study and those previously published for $\mathrm{Ab}$ originals in Bourke [5], the only other population of New South Wales Aboriginals for which similar data are available.

\section{$H L A$ antigens and grandparental origin}

HLA typing was available for 133 individuals from 27 families. In 10 individuals, typing was carried out only for Class I antigens since insufficient B cells were obtained for Class II typing. From the families, 60 distinct haplotypes were identified. These included the characteristically Caucasian HLA A1, B 8, Cw 7, DR3; A3, B7, DR 3 and A29, B44, DR7. Typically Aboriginal haplotypes appeared to be $\mathrm{A} 24, \mathrm{Bw} 56, \mathrm{Cw} 1, \mathrm{DRw} 13$; Aw 24, Bw 62, Cw 4, DR4; Aw 34, Bw61, DR4; Aw 34, Bw 61, DR2 and Aw 34, Bw61, DRw 14. 58 individuals were identified who lacked either first or second degree relatives in the group as a whole. Of these 58 unrelated individuals, 33 carried antigens not usually found in Aboriginals, indicating not less than 57\% admixture. A further 3 individuals carried $\mathrm{Bw} 46, \mathrm{Cw} 1,3$ a typical Mongoloid haplotype.

Admixture may be further estimated by examining the gene frequencies of non-Aboriginal antigens in this group of subjects compared with those observed in Caucasoid Australian blood donors. The results of estimates for blood groups A2 and 5 individual HLA antigens, which are known [18] to have a very low or zero gene frequency in Aboriginals, are shown in Table 3. The Caucasoid admixture based on the average of these estimates is $61 \%$, which approximates to the $57 \%$ defined from the number of individuals carrying 'foreign' or introduced antigens.

The data on grandparental origin was unsatisfactory in several respects. About a third of the subjects asked were uncertain of the status of at least one of their grandparents. Six of the subjects claimed to have four 'full-blooded' grandparents, which was considered unlikely by the Aboriginal workers assisting with the field work. For these reasons the data on grandparental origin were not used except for identifying non-Aboriginal subjects since, in these few cases, the subjects were certain that none of their grandparents were Aboriginal. No analyses have yet been undertaken on the extent of intra-familial correlation regarding glucose tolerance.

\section{Diabetes prevalence in Aboriginal subjects}

Nine individuals in the study population (including the 2 with previously diagnosed diabetes referred to above) were non-Aboriginal. When these are removed from numerator and denominator, the crude prevalence of diabetes (previously diagnosed plus newly diagnosed) 
Table 4. Plasma glucose and insulin values (means \pm SEM) before and $2 \mathrm{~h}$ after $75 \mathrm{~g}$ of oral glucose, Aboriginal and non-Aboriginal subjects

\begin{tabular}{|c|c|c|c|c|}
\hline & \multirow{2}{*}{$\begin{array}{l}\text { Non- } \\
\text { aboriginals } \\
(n=7)\end{array}$} & \multirow{2}{*}{$\begin{array}{l}\text { Aboriginals } \\
(n=118)\end{array}$} & \multicolumn{2}{|c|}{$\begin{array}{l}\text { Aboriginals divided } \\
\text { into }\end{array}$} \\
\hline & & & $\begin{array}{l}\text { Group 1 } \\
(n=68)\end{array}$ & $\begin{array}{l}\text { Group } 2^{b} \\
(n=50)\end{array}$ \\
\hline $\begin{array}{l}\text { Fasting glucose } \\
(\mathrm{mmol} / \mathrm{l})\end{array}$ & $\begin{array}{l}4.5 \\
( \pm 0.2)\end{array}$ & $\begin{array}{l}4.7 \\
( \pm 0.1)\end{array}$ & $\begin{array}{l}4.7 \\
( \pm 0.2)\end{array}$ & $\begin{array}{l}4.8 \\
( \pm 0.1)\end{array}$ \\
\hline $\begin{array}{l}2 \mathrm{~h} \text { glucose } \\
(\mathrm{mmol} / \mathrm{l})\end{array}$ & $\begin{array}{l}4.3 \\
( \pm 0.3)\end{array}$ & $\begin{array}{l}4.7 \\
( \pm 0.2)\end{array}$ & $\begin{array}{c}4.6 \\
( \pm 0.3)\end{array}$ & $\begin{array}{l}4.8 \\
( \pm 0.3)\end{array}$ \\
\hline $\begin{array}{l}\text { Fasting insulin } \\
(\mathrm{mU} / \mathrm{l})\end{array}$ & $\begin{array}{l}5.3 \\
( \pm 0.6)\end{array}$ & $\begin{array}{l}12.4^{\mathrm{c}} \\
( \pm 1.2)\end{array}$ & $\begin{array}{l}12.7 \\
( \pm 1.6)\end{array}$ & $\begin{array}{l}12.0 \\
( \pm 0.3)\end{array}$ \\
\hline $\begin{array}{l}2 \mathrm{~h} \text { insulin } \\
(\mathrm{mU} / \mathrm{l})\end{array}$ & $\begin{array}{l}13.5 \\
( \pm 2.5)\end{array}$ & $\begin{array}{l}30.4^{c} \\
( \pm 3.7)\end{array}$ & $\begin{array}{l}26.0 \\
( \pm 4.3)\end{array}$ & $\begin{array}{l}36.0 \\
( \pm 6.3)\end{array}$ \\
\hline $\begin{array}{l}\text { Rise in insulin } \\
(\mathrm{mU} / \mathrm{l})\end{array}$ & $\begin{array}{l}8.2 \\
( \pm 2.2)\end{array}$ & $\begin{array}{l}18.0^{\mathrm{c}} \\
( \pm 3.4)\end{array}$ & $\begin{array}{l}13.3 \\
( \pm 3.8)\end{array}$ & $\begin{array}{l}24.0 \\
( \pm 6.1)\end{array}$ \\
\hline $\begin{array}{l}\text { Body mass index } \\
\left(\mathrm{kg} / \mathrm{m}^{2}\right)\end{array}$ & $\begin{array}{l}22.6 \\
( \pm 0.9)\end{array}$ & $\begin{array}{l}25.5^{\mathrm{c}} \\
( \pm 0.5)\end{array}$ & $\begin{array}{l}24.8 \\
( \pm 0.7)\end{array}$ & $\begin{array}{l}26.5 \\
( \pm 0.7)\end{array}$ \\
\hline
\end{tabular}

a Group $1=$ Aboriginal subjects with at least one non-Aboriginal HLA haplotype ${ }^{b}$ Group $2=$ Aboriginal subjects with no identifiable non-Aboriginal HLA haplotype; ${ }^{c}$ Statistically significant difference compared with non-Aboriginal group $(p<0.05)$

in Aboriginal subjects is $8.1 \%(6.8 \%$ in men and $9.7 \%$ in women). The age sex distribution of the study population differed slightly from that of the 1981 New South Wales Aboriginal census population [19]. When the prevalence figures for the present study are age-sex standardised (by the direct method) using the $1981 \mathrm{New}$ South Wales Aboriginal census population as standard, the prevalence of diabetes is $7.8 \%$ (95\% confidence limits $4.2 \%$ and $11.4 \%$ ). This figure is directly comparable to the standardised prevalence of $15.6 \%$ (confidence limits 11.5\% and 19.7\%) described for Bourke [5].

\section{Glucose tolerance and genetic admixture}

OGTT results for subjects of known HLA status, excluding those with previously diagnosed diabetes, are shown in Table 4. The small group of non-Aboriginal subjects showed lower mean values for fasting glucose, $2 \mathrm{~h}$ glucose, fasting insulin and $2 \mathrm{~h}$ insulin compared with Aboriginal subjects. The differences in insulin values are statistically significant $(p<0.05)$. The Aboriginal group were also significantly heavier $(p<0.05)$ for their height than the non-Aboriginal group. Aboriginal subjects showed a greater range in these values than did non-Aboriginal subjects. These differences persist when male subjects only are compared (not shown). The nonAboriginal group contained only two female subjects; hence a similar comparison for females is not possible.

Aboriginal subjects may be further divided into two groups, those with at least one identifiable non-Aboriginal HLA haplotype (group 1) and those with no identifiable non-Aboriginal HLA haplotype (group 2). These groups contain roughly equal proportions of men and women (36 men and 32 women in group, 1, 26 men and 24 women in group 2). Mean fasting glucose, $2 \mathrm{~h}$ glucose, $2 \mathrm{~h}$ insulin, rise in insulin and mean body mass are all greater in group 2 than in group 1, though none of these differences reach statistical significance. However, significant $(p<0.05)$ linear trends of increasing mean $2 \mathrm{~h}$ insulin levels, rise in insulin and body mass index are found for both sexes considered together (Table 4). For men, trends are present for fasting insulin, $2 \mathrm{~h}$ insulin levels and mean body mass index (not shown).

\section{Discussion}

The Aboriginal people of Australia are the descendents of at least three waves of migrants from South East Asia who began arriving in Australia about 50,000 years ago [20]. Early studies of HLA antigens in groups of Aboriginals from widely separated regions of the central desert [18] and from the Northern Territory and Western Australia [21] have indicated remarkable homogeneity of the Aboriginal people and little, if any, Caucasoid admixture. However, in the South and East of Australia admixture from non-Aboriginal sources is known to have taken place, though no quantitative studies have been published prior to this report. Genetic admixture is also known to be important in the epidemiology of Type 2 diabetes. A sub-population of Naruan islanders in which 'foreign' genes could be demonstrated showed a lower prevalence of diabetes than 'full-blooded' subjects [10], and a gradient of increasing mean plasma glucose concentrations has been described in six Pacific populations with increasing Austronesian genetic admixture [11].

The prevalence estimates from the present study can be legitimately compared with those from Bourke [5], though the relatively small sizes of the populations, especially in this study, need to be bourne in mind. The validity of the comparison is, however, strengthened by the short time interval between the field work carried out in the two communities ( 2 years) and the fact that, in both studies, subjects were selected in the same manner (all adults), the methods of testing for diabetes and impaired glucose tolerance was identical ( $75 \mathrm{~g}$ OGTT) and diagnoses were based on a combination of initial and $2 \mathrm{~h}$ venous plasma glucose values. There are small differences in the criteria for the definition of diabetes and impaired glucose tolerance, in that the Bourke data were assessed according to the Second Report of the World Health Authority Expert Committee on Diabetes Mellitus [22] in which plasma glucose values were rounded to the nearest $\mathrm{mmol} / \mathrm{l}$. In the criteria employed in this study, the values used had been rounded to the nearest tenth of a mmol/1 [16]; this does not, however, alter the prevalence figures. Valid comparison of either study with earlier studies [1-4] is rendered unsatisfactory by the numerous methodological differences and the 
ways in which results have been analysed and presented.

The age-sex standardised prevalence of diabetes in the Aborigines of the Purfleet and Forster communities $(7.8 \%)$ is significantly lower than the $15.6 \%$ found in Bourke. The age-sex standardised prevalence of impaired glucose tolerance is not significantly different in the 2 communities. The difference in the prevalence of diabetes cannot be attributed simply to a difference in adiposity, since there are no convincing differences between mean body mass index values in subjects of either sex throughout the age range studied.

Possible explanations for this difference in diabetes prevalence include environmental differences, genetic differences or a combination of both. There is insufficient information currently available on environmental factors such as diet and physical activity to rule out present environmental factors as an explanation. It is known, however, that the Bourke Aborigines originated from the North West corner of New South Wales, an arid and relatively hostile environment, and were forcibly resettled first in Brewarrina and then in Bourke.Purfleet and Forster Aborigines are mostly derived from the Biripi and other New South Wales coastal tribes. It is likely, though currently unsubstantiated, that there may have been important differences in the environment in Northwestern and coastal New South Wales during the millenia of hunting and gathering carried out by the ancestors of these 2 groups. These differing environments may have provided a greater selective pressure for the 'thifty genotype' in inland New South Wales than at the coast.

Alternatively, or perhaps in addition, the lower prevalence of diabetes in the coastal group may, as suggested in studies outside Australia [10-13], be the result of genetic admixture from non-Aboriginal sources. Insulin responses to oral glucose and objective genetic data on degree of Aboriginality are not yet available for the Bourke population. However, it is likely, in view of their known recent history, that they have been subjected to genetic admixture from non-Aboriginal sources to a lesser extent than the Purfleet and Forster population.

There are insufficient numbers of diabetic individuals in this sample to allow a valid comparison of prevalence estimates in those with and those without evidence of non-Aboriginal admixture. However, the results available for metabolic response to oral glucose in men and women combined and in men considered alone suggest a gradient in response with highest values for subjects with no demonstrable non-Aboriginal HLA haplotypes, intermediate levels in those with at least one non-Aboriginal haplotype and lowest levels in those known to be non-Aboriginal. These findings should be compared with those of O'Dea and colleagues [23-25], which show greater insulin responses to oral starch in Aboriginal subjects compared with Caucasians [23]. Fasting plasma glucose concentrations have been shown to be higher in Aboriginal subjects [24]. When diabetic urban dwelling Aborigines revert to a 'bush' lifestyle [25], they lose weight and their glucose tolerance improves. These and the results of the present study suggest that Aboriginal subjects display a markedly different metabolic response to oral carbohydrate compared with non-Aboriginals.

The results of this study also suggest that, in a group of coastal Aboriginal people who have been subject to considerable genetic admixture from non-Aboriginal sources, diabetes is less prevalent than would be expected on the basis of epidemiological data from a similar study of Aboriginal people from central New South Wales.

Acknowledgements. This study would not have been possible without the permission of the Board of Directors of the Biripi Medical Centre, Purfleet and the cooperation of the members of the Purfleet and Forster communities. Dr. G. Fuller of the North Coast Pathology Service (Taree) and Drs. J.Dickeson and C. Hall of the Hunter Biochemistry Service (Newcastle) gave invaluable support, as did their staff. Field workers Ms. J.French, P. Kellner, Z. Moran, S.-A. Russell, G. Donovan, Mr. T. McDonald and Ms. P. Davis assisted greatly in the collection of the data. DRRW participated in the research while on sabbatical leave from the University of Cambridge, funded in part by the University of Cambridge Staff Travel Fund, the British Diabetic Association and Novo Laboratories Ltd. The work was largely funded by a grant from the Hunter Region Health Department.

\section{References}

1. Wise PH, Edwards FM, Thomas DW (1970) Hyperglycaemia in the urbanized Aboriginal. The Davenport study. Med J Aust 2: $1001-1006$

2. Wise PH, Edwards FM, Craig RJ, Evans B, Murchland JB, Sutherland B, Thomas DW (1976) Diabetes and associated variables in the South Australian Aboriginal. Aus N Z J Med 6: 191-196

3. Bastian P (1979) Coronary heart disease in tribal Aborigines - the West Kimberley Survey. Aust N Z J Med 9:284-292

4. Kamien $M$ (1976) The physical health of Aboriginal adults in Bourke, New South Wales. Med J Aust Spec Supplement 38-44

5. Cameron WI, Moffitt PS, Williams DRR (1986) Diabetes mellitus in the Australian Aborigines of Bourke, New South Wales. Diabetes Research and Clinical Practice 2: 307-314

6. Welbourn TA, Curnow DH, Wearne JT (1966) Diabetes detected by blood-sugar measurement after a glucose load: report from the Busselton survey. Med J Aust 2: 778-783

7. Glatthaar C, Welbourn TA, Stenhouse NS, Garcia-Webb P (1985) Diabetes and impaired glucose tolerance: a prevalence estimate based on the Busselton 1981 survey. Med J Aus 143: 436-440

8. Zimmet P, Kirk R, Serjeantson S, Whitehouse S, Taylor T (1982) Diabetes in Pacific populations - genetic and environmental interactions. In: Melish JS, Hanna J and Baba S (eds) Genetic Environmental Interaction in Diabetes Mellitus. Excerpta Medica, Amsterdam, p 9-17

9. Neel JV (1962) Diabetes mellitus: a "thrifty" genotype rendered detrimental by progress? Am J Hum Genet 14: 353-362

10. Serjeantson SW, Owerbach D, Zimmet P, Nerup J, Thoma $K$ (1983) Genetics of diabetes in Nauru: effects of foreign admixture, HLA antigens and the insulin-gene-linked polymorphism. Diabetologia 25: 13-17

11. King H, Zimmet $P$, Bennett $P$, Taylor R, Raper LR (1984) Glucose tolerance and ancestral genetic admixture in six semitraditional Pacific populations. Genetic Epidemiology 1: 315-328

12. Gardner LI, Stern MP, Haffner SM, Gaskill SP, Hazuda HP, Relethford JH, Eifler CW (1984) Prevalence of diabetes in Mexican Americans: relationship to percent of gene pool derived from native American sources. Diabetes 33: 86-92 
13. Brosseau JD, Eelkema RC, Crawford AC, Abe TA (1979) Diabetes among the three affiliated tribes: Correlation with degree of Indian inheritance. Am J Public Health 69: 1277-1288

14. Terasaki P (ed) UCLA (1980) Eighth Workshop Joint Reports in Histocompatibility Testing 1980.

15. Albert Ed, Baur MP, Mayr WR (eds) (1985) Ninth Workshop Joint Reports in Histocompatibility Testing 1984. Springer, Berlin

16. Diabetes mellitus: report of a WHO study group (1985) Technical Report Series 727. WHO, Geneva, $p 11$

17. Bennett PH (1979) Standardization of methods and reporting of tests in epidemiologic studies. Diabetes Care 2: 98-104

18. Bashir HV, Macqueen JM, Amos DB, Guinan JJ, Johnston JM, Brotherton JVM, Boettcher B, Ashton J (1972) A study of the HLA system in an Australian Aboriginal population. In: Dausset J, Colombani J (eds) Histocompatibility Testing. Munksgaard, Copenhagen, $\mathrm{p} 311$

19. Australian Board of Census and Statistics (1973) 1971 Census of Population and Housing Bulletin 9. The Aboriginal Population, Bureau of Census and Statistics, Canberra

20. Serjeantson SW, Ryan DP, Thompson AR (1982) The colonization of the Pacific: the story according to human leukocyte antigens. Am J Hum Genet 34: 904-918

21. Cross RA, Alpers MP, York TJ, Davey MG, Pollard M, Kirk RL, Blake NM, McDermid EM, Law W, Morris PJ (1972) Studies of
HLA in Australian Aborigines. In: Dausset J, Colombani J (eds) Histocompatibility Testing. Munksgaard, Copenhagen, p 311

22. World Health Organisation Expert Committee on Diabetes Mellitus - Second Report (1980) Technical Report Series 646. WHO, Geneva, $\mathrm{p} 10$

23. O'Dea K, Spargo RM, Akerman K (1980) The effect of transition from traditional to urban life-style on the insulin secretory response in Australian Aborigines. Diabetes Care 3:31-37

24. O'Dea K, Spargo RM, Nestel PJ (1982) Impact of westernization on carbohydrate and lipid metabolism in Australian Aborigines Diabetologia 22: 148-153

25. O'Dea K (1984) Marked improvement in carbohydrate and lipid metabolism in diabetic Australian Aborigines after temporary reversion to traditional lifestyle. Diabetes 33: 596-603

Received: 26 June 1986

and in revised form: 18 December 1986

Dr. D. R. R. Williams

University Department of Community Medicine

Addenbrooke's Hospital

Cambridge CB2 2QQ

UK 